\title{
Antagonistic rhizobacteria and jasmonic acid induce resistance against tomato bacterial spot
}

\author{
Hélvio Gledson Maciel Ferraz (*); Renata Sousa Resende; Poliana Coutinho Moreira; \\ Patrícia Ricardino Silveira; Elisângela Aparecida Milagres; José Rogério Oliveira; \\ Fabrício Ávila Rodrigues \\ Universidade Federal de Viçosa (UFV), Department of Plant Pathology, Av. Peter H. Rolfs, s/n, 36570-900 Viçosa (MG), Brasil. \\ (*) Corresponding author: hgmferraz@yahoo.com.br
}

Received: Feb. 25, 2015; Accepted: June 24, 2015

\begin{abstract}
Tomato bacterial spot on tomato may be caused by four species of Xanthomonas and among them X. gardneri $(\mathrm{Xg})$ is the most destructive one, especially in areas irrigated using a center pivot system in Minas Gerais state and the midwest region of Brazil. Due to the ineffectiveness of chemical control and the lack of cultivars with high levels of genetic resistance, this study investigated the potential of three antagonists (Streptomyces setonii (UFV618), Bacillus cereus (UFV592) and Serratia marcescens (UFV252)), and the hormone jasmonic acid (JA) as a positive control, to reduce bacterial spot symptoms and to potentiate defense enzymes in the leaves of tomato plants infected by $\mathrm{Xg}$. Tomato seeds were microbiolized with each antagonist, and the soil was drenched with these bacteria. The plants were sprayed with JA $48 \mathrm{~h}$ before $\mathrm{Xg}$ inoculation. The final average severity on the tomato plants was reduced by 29.44, 59.26 and 61.33\% in the UFV592, UFV618 and JA treatments, respectively. The UFV618 antagonist was as effective as JA in reducing bacterial spot symptoms on tomatoes, which can be explained by the greater activities of defense enzymes that are commonly involved in host resistance against bacterial diseases. These results suggest that JA and the UFV618 antagonist can be used in the integrated management of bacterial spot on tomatoes.
\end{abstract}

Key words: Xanthomonas gardneri, Solanum lycopersicum, biological control, host defense mechanisms, induced resistance.

\section{INTRODUCTION}

Tomato bacterial spot is one of the most important foliar diseases affecting tomato in Brazil and frequently occurs at all plant growth stages in areas irrigated using a center pivot system (Lopes \& Stripari, 1998). Xanthomonas gardneri (Xg) (ex Sutic 1957) Jones et al., 2006 is a bacterial species that has prevailed in surveys conducted on tomato plants exhibiting symptoms of bacterial spot in the states of Minas Gerais and Goiás (Quezado-Duval et al., 2004). Despite the importance of bacterial spot in tomato, there are no registered products to control this disease (Brasil, 2015). Biological control and the application of resistance inducers may be a viable strategy for crops that do not have registered pesticides or for which registered products appear to be ineffective (Ferraz et al., 2014; Lanna et al., 2013; Shanmugam \& Kanoujia, 2011). In this context, the utilization of resistance induced by non-pathogenic bacteria and abiotic inducers for disease control in agronomic crops has increased in recent years (Ferraz et al., 2014; Lanna et al., 2013; Nafie et al., 2011; Van Loon, 2007). In addition, there is an increasing demand by society for healthier food and less harm to the environment.
Beneficial soil-borne microorganisms such as Trichoderma, Fusarium, Streptomyces, Bacillus and Actinomyces spp. have been reported to protect plants against pathogenic microorganisms through a range of mechanisms, including competition for space and (micro) nutrients; hyperparasitism; antagonism via microbial production of secondary metabolites, such as iron-chelating siderophores, antibiotics, and lytic enzymes; and elicitation of induced systemic resistance (ISR) (Pieterse et al., 2014). According to Van Loon et al. (1998), some microorganisms may act indirectly on pathogens, activating latent defense mechanisms in plants. This control is not due to the direct action of antimicrobial factors but lies in the ability of the inducer to sensitize the plant, which results in the activation of latent structural and biochemical defense mechanisms against potential pathogen attack (Kúc, 2001). ISR emerged as an important mechanism by which selected plant growth-promoting bacteria and fungi in the rhizosphere prime the whole plant body for enhanced defense against a broad range of pathogens (Pieterse et al., 2014). 
Generally, ISR is promoted by beneficial microorganisms or by herbivory, and the hormones ethylene and jasmonic acid mediate this signaling pathway. By contrast, systemic acquired resistance (SAR) is usually induced by pathogens or abiotic elicitors, and the signaling pathway is mediated by salicylic acid (Romeiro, 2007). However, several plant growth promoting rhizocbacteria have been reported to trigger a salicylic acid-dependent type of ISR that resembles pathogen-induced SAR (Pieterse et al., 2014).

Key enzymes such as phenylalanine-ammonia lyases, peroxidases and polyphenoloxidases, and some pathogenesis-related (PR) proteins are produced in the SAR and ISR pathways (Yoshikawa et al., 1983). Some examples of PR proteins related to SAR are $\beta-1,3$-glucanases and chitinases, which belong to the PR-2 and PR-3 families, respectively (Van Loon et al., 2006).

The present study aimed to investigate the potential of three antagonists, previously selected from a universe of 635 isolates to reduce bacterial spot symptoms on the leaves of tomato plants infected by $\mathrm{Xg}$ as well as to potentiate defense enzyme activities.

\section{MATERIALS AND METHODS}

\section{Source of $\mathrm{Xg}$ and antagonists, cultivation and preservation}

Xanthomonas gardneri (LBPCB 17) was previously identified by the band profile generated by BOX-PCR (Louws et al., 1995) and obtained from the Bacterial Culture Collection of the Bacteriology Laboratory of Plants of the Department of Plant Pathology at Viçosa Federal University. The antagonists UFV252, UFV592, and UFV618 were selected from a universe of 635 bacterial isolates that promote biocontrol of Fusarium wilt (Ferraz et al., 2014), bacterial spot and early blight and in tomato plants. The antagonists were identified as Serratia marcescens (UFV252), Bacillus cereus (UFV592) and Streptomyces setonii (UFV618) by sequencing the $16 \mathrm{~S} r \mathrm{DNA}$ fragment, with the following numbers deposited in GenBank: KM463767, KM463766 and KM 463768, respectively. $\mathrm{Xg}$ and the antagonists UFV592 and UFV252 were cultured in 523 medium (Kado \& Heskett, 1970), and the actinomycete UFV618 was cultured in soil-extract agar (Pramer \& Schmidt, 1964). Bacterial and actinomycete cultures were preserved in glycerol (30\%) and stored in an ultrafreezer at $-80{ }^{\circ} \mathrm{C}$ (Romeiro, 2005).

\section{Plant growth, antagonist application and jasmonic acid spraying}

Tomato plants were grown in plastic pots containing $2 \mathrm{~kg}$ of a substrate composed of a mixture of sterilized soil, manure and sand in a 3:1:1 ratio (v:v:v). Monobasic calcium phosphate $(1.63 \mathrm{~g})$ was added per each $\mathrm{kg}$ of substrate. Six seeds were sown per plastic pot, and after their emergence, one plant was retained per pot. Fifteen days after sowing, all plants received $100 \mathrm{~mL}$ of a nutrient solution containing, in $\mathrm{mg} \mathrm{L}^{-1}, 192 \mathrm{KCl}, 104.42 \mathrm{~K}_{2} \mathrm{SO}_{4}, 150.35 \mathrm{MgSO}_{4} \cdot 7 \mathrm{H}_{2} \mathrm{O}$, 61 urea, $0.27 \mathrm{NH}_{4} \mathrm{MO}_{7} \mathrm{O}_{24} \cdot 4 \mathrm{H}_{2} \mathrm{O}, 1.61 \mathrm{H}_{3} \mathrm{BO}_{3}, 6.67 \mathrm{ZnSO}_{4}$, $1.74 \mathrm{CuSO}_{4} \cdot 5 \mathrm{H}_{2} \mathrm{O}, 4.10 \mathrm{MnCl}_{2} \cdot 4 \mathrm{H}_{2} \mathrm{O}, 4.08 \mathrm{FeSO}_{4} \cdot 7 \mathrm{H}_{2} \mathrm{O}$ and 5.58 bisodium EDTA. The nutrient solution was re-applied at the second and third weeks after sowing. The plants were maintained in a greenhouse at a temperature of $20 \pm 5^{\circ} \mathrm{C}$ and relative humidity of $75 \pm 2 \%$ and irrigated daily. The tomato seeds (cv. "Santa Clara") were microbiolized with three antagonist suspensions for $12 \mathrm{~h}$ and then sown in plastic pots. Five days before inoculation with $\mathrm{Xg}$, a 50 -mL suspension of each antagonist was added to each pot. To obtain the suspensions, the optical density at $540 \mathrm{~nm}$ was adjusted to $0.5\left(\approx 5 \times 10^{10} \mathrm{CFU} \mathrm{mL}^{-1}\right)$ by adding $\mathrm{Nacl} 0.85 \%(\mathrm{~m} / \mathrm{v})$ to the bacterial culture. At 35 days after sowing, the plants receiving the JA treatment were sprayed with a JA solution (0.5 mM) (Sigma-Aldrich, São Paulo) (25 mL per plant) 48 hours before inoculation with $X g$ (Fujimoto et al., 2011). The plants were maintained in closed chambers for 12 hours after JA spraying, after this period of time the plants were kept in a greenhouse with the plants of the other treatments. The plants from non-microbiolized seeds that were sprayed with distilled water served as the control treatment.

\section{Inoculation of tomato plants with $\mathrm{Xg}$ and evaluation of bacterial spot severity}

The plants with the fully expanded fifth pair of trifoliolate leaves (37 days after sowing), from the base to the apex, were inoculated with an aqueous suspension of $X g$. To obtain the suspension, the optical density at $540 \mathrm{~nm}$ was adjusted to 0.2 $\left(\approx 2 \times 10^{8} \mathrm{CFU} \mathrm{mL}^{-1}\right)$ by adding $\mathrm{Nacl} 0.85 \%(\mathrm{~m} / \mathrm{v})$ to the bacterial culture. Before and after inoculation, plants were placed in a chamber at $25 \pm 2{ }^{\circ} \mathrm{C}$, with a relative humidity of $80 \pm 5 \%$ and a photoperiod of 12 hours for 24 hours. The plants were transferred to a greenhouse (temperature ranging from 18 to $27^{\circ} \mathrm{C}$ and relative humidity of $75 \pm 5 \%$ ) $24 \mathrm{~h}$ after inoculation. Bacterial spot severity was estimated at 7, 12 and 18 days after inoculation (dai) using the diagrammatic proposed by Mello et al. (1997). One plant per replication was used to evaluate the bacterial spot severity. The data obtained were used to calculate the area under the bacterial spot progress curve (AUBSPC) according to the formula proposed by Shaner \& Finney (1997).

\section{Population dynamics of the antagonists UFV252, UFV592 and UFV618 in the rhizosphere and rhizoplane of tomato plants}

Semi-selective media were prepared based on the constitutive multidrug resistance of the antagonists UFV252, UFV592 and UFV618 to antibiotics according to Ferraz et al. (2010). 
Specific antibiotics (ampicillin, cefadroxil and tetracycline (30 $\mathrm{mg} \mathrm{mL}^{-1}$ ) for UFV252; cefepime and trimethoprim (60 $\left.\mathrm{mg} \mathrm{mL}^{-1}\right)$ for UFV592 and trimethoprim and oxacillin (30 $\mathrm{mg} \mathrm{mL}^{-1}$ ) for UFV618) were added to the 523 medium. To prevent fungal growth, cycloheximide $\left(150 \mathrm{mg} \mathrm{mL}^{-1}\right)$ was added to the semi-selective media. The antagonists were quantified in the semi-selective media at the following times: before the second antagonist application to the soil, immediately after the second antagonist application and at 8 , 15, 22 and 37 days after the second antagonist application. To quantify the antagonists at each evaluation time, a soil sample was collected from around the stem of each plant at a distance of approximately $1 \mathrm{~cm}$ from the stem and $7 \mathrm{~cm}$ deep using a spatula. Then, the samples from each replication were homogenized, weighed and transferred to an Erlenmeyer flask containing $200 \mathrm{~mL}$ of sterilized Nacl $0.85 \%(\mathrm{~m} / \mathrm{v})$ and Tween $80(0.05 \%)$ and subjected to ultrasonic radiation for $25 \mathrm{~min}$ to extract the antagonists.

The suspension was serially diluted and placed into test tubes containing sterile Nacl $0.85 \%(\mathrm{~m} / \mathrm{v})$ and Tween $80(0.05 \%)$. Then, $100 \mu \mathrm{L}$ of the suspension dilutions $\left(10^{-1}\right.$ to $\left.10^{-8}\right)$ was added to Petri dishes containing semi-selective media specific for the antagonists (solid 523 medium with specific antibiotics). The suspension was spread using a Drigalski handle, and the plates were transferred to a growth chamber at $28{ }^{\circ} \mathrm{C}$ for 24 hours. After this period, the number of colonies per plate was counted. The suspension obtained from the tomato plants that were not treated with any antagonist was plated in each of the semi-selective media as the control treatment.

\section{Determination of the activities of peroxidases (POX, EC1.11.1.7), polyphenoloxidases (PPO, EC 1.10.3.1), $\beta$-1,3-glucanases (GLU, EC 3.2.1.39), chitinases (CHI, 3.2.1.14), phenylalanine ammonia-lyases (PAL, EC 4.3.1.5) and lipoxygenases (LOX, EC 1.13.11.12)}

Leaf samples from each replication and treatment were collected at 2, 5 and 11 dai. Leaf samples also were collected immediately before inoculation ( 0 dai). After sampling, the leaf samples were stored individually in aluminum foil, rapidly frozen in liquid nitrogen and then stored in an ultrafreezer at $-80{ }^{\circ} \mathrm{C}$ until further analysis.

To obtain the extracts used to determine the activities of POX, PPO, GLU, CHI and PAL, $0.3 \mathrm{~g}$ of leaf tissue was macerated in a mortar using liquid nitrogen and polyvinylpyrrolidone (PVP) $1 \%(\mathrm{w} / \mathrm{v})$ to obtain a fine powder. The powder was homogenized in $2 \mathrm{~mL}$ of $50 \mathrm{mM}$ sodium phosphate buffer ( $\mathrm{pH}$ 6.5) containing $1 \mathrm{mM}$ phenylmethylsulfonicfluoride (PMSF). The homogenized material was centrifuged at $20,000 \times g$ for $25 \mathrm{~min}$ at $4{ }^{\circ} \mathrm{C}$, and the supernatant was used to determine the enzyme activities. The POX and PPO activities were determined by the oxidation of pyrogallol according to the method of Kar \& Mishra (1976). To determine POX activity, a mixture containing $300 \mu \mathrm{L}$ of distilled water, $280 \mu \mathrm{L}$ of $100 \mathrm{mM}$ potassium phosphate buffer ( $\mathrm{pH}$ 6.8), $200 \mu \mathrm{L}$ of $100 \mathrm{mM}$ pyrogallol and $200 \mu \mathrm{L}$ of $100 \mathrm{mM}$ hydrogen peroxide was added to $20 \mu \mathrm{L}$ of the extract. To determine PPO activity, a mixture containing $300 \mu \mathrm{L}$ of distilled water, $280 \mu \mathrm{L}$ of $100 \mathrm{mM}$ potassium phosphate buffer $(\mathrm{pH}$ 6.8) and $200 \mu \mathrm{L}$ of $100 \mathrm{mM}$ pyrogallol was added to $20 \mu \mathrm{L}$ of the extract. The absorbance was measured at $420 \mathrm{~nm}$ every 10 seconds for $1 \mathrm{~min}$ after the addition of the extract to the mixture (a total of five readings) using a spectrophotometer (Evolution 60, Thermo Scientific, Waltham, MA, USA). A molar extinction coefficient of $2.47 \mathrm{mM}^{-1} \mathrm{~cm}^{-1}$ was used to calculate the POX and PPO activities (Chance \& Maehly, 1955), which were expressed as $\mathrm{mM}$ and $\mu \mathrm{M}$ of purpurogallin produced $\mathrm{min}^{-1} \mathrm{mg}^{-1}$ of protein, respectively. Throughout the process, the microcentrifuge tubes were covered with aluminum foil to protect the mixture from oxidation by light. The GLU activity was determined as described by Lever (1972). The reaction was initiated by the addition of a $20-\mu \mathrm{L}$ aliquot of the supernatant to a mixture of $230 \mu \mathrm{L}$ of $100 \mathrm{mM}$ sodium acetate buffer ( $\mathrm{pH}$ 5.0) and $250 \mu \mathrm{L}$ of the substrate laminarin (Sigma-Aldrich, São Paulo) at a concentration of $4 \mathrm{mg} \mathrm{mL}^{-1}$. The reaction mixture was incubated in a water bath for $30 \mathrm{~min}$ at $45^{\circ} \mathrm{C}$. After the incubation period, the amount of reducing sugars was determined by adding $250 \mu \mathrm{L}$ of dinitrosalicylic acid to the mixture and then incubating the resulting mixture in a water bath for $15 \mathrm{~min}$ at $100{ }^{\circ} \mathrm{C}$. The reaction was terminated by cooling the samples in an ice bath. The same reaction mixture was used for the control samples except that the dinitrosalicylic acid was added at the same time as the extract. The absorbance of the product released by GLU was measured at $540 \mathrm{~nm}$ and the activity of GLU was expressed as absorbance units $\mathrm{min}^{-1} \mathrm{mg}^{-1}$ of protein. $\mathrm{CHI}$ activity was determined following the method of Roberts \& Selitrennikoff (1988) modified by Harman et al. (1993). The reaction was initiated by the addition of a $20-\mu \mathrm{L}$ aliquot of the supernatant to a mixture of $470 \mu \mathrm{L}$ of $50 \mathrm{mM}$ sodium acetate buffer ( $\mathrm{pH}$ 5.0) and $10 \mu \mathrm{L}$ of the substrate $p$-nitrophenyl- $\beta$-DN-Ni-diacetilquitobiose (Sigma-Aldrich, São Paulo) at a concentration of $2 \mathrm{mg} \mathrm{mL}^{-1}$. The reaction mixture was incubated in a water bath at $37^{\circ} \mathrm{C}$ for $2 \mathrm{~h}$. The reaction was terminated by the addition of $500 \mu \mathrm{L}$ of $0.2 \mathrm{M}$ sodium carbonate. In the control samples, only the sodium carbonate was used after adding the extract to the reaction mixture and the samples were incubated in a water bath at $37^{\circ} \mathrm{C}$ for 2 hours. The absorbance of the final product released by the chitinase was determined at $410 \mathrm{~nm}$. A molar extinction coefficient of $7 \times 10^{4} \mathrm{mM} \mathrm{cm}^{-1}$ was used to calculate $\mathrm{CHI}$ activity, which was expressed as $\mathrm{nmol} \mathrm{min}{ }^{-1} \mathrm{mg}^{-1}$ of protein. PAL activity was determined by adding $100 \mu \mathrm{L}$ of the extract to a mixture containing $400 \mu \mathrm{L}$ of $25 \mathrm{mM}$ Tris- $\mathrm{HCl}$ buffer ( $\mathrm{pH} 8.8$ ) and $500 \mu \mathrm{L}$ of $100 \mathrm{mM} L$-phenylalanine. The reaction mixture was incubated 
in a water bath at $30^{\circ} \mathrm{C}$ for $4 \mathrm{~h}$. In the control samples, the $L$-phenylalanine was replaced with $500 \mu \mathrm{L}$ of Tris- $\mathrm{HCl}$ buffer. The reaction was finalized by adding $60 \mu \mathrm{L}$ of $6 \mathrm{~N} \mathrm{HCl}$. The absorbance of the trans-cinnamic acid derivatives was measured at $290 \mathrm{~nm}$ using a spectrophotometer and a molar extinction coefficient of $10^{4} \mathrm{mM}^{-1} \mathrm{~cm}^{-1}$ (Zucker, 1965) was used to calculate PAL activity, which was expressed as

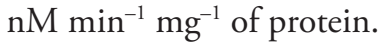

To obtain the extract for LOX activity, $0.2 \mathrm{~g}$ of leaf tissue was macerated in a mortar using liquid nitrogen to obtain a fine powder. The powder was homogenized in $2 \mathrm{~mL}$ of $20 \mathrm{mM}$ sodium phosphate buffer ( $\mathrm{pH}$ 6.8) containing Triton X-100 1\% (v/v) and PVP 1\% (w/v). The homogenized material was centrifuged at $15,000 \times g$ for $10 \mathrm{~min}$ at $4{ }^{\circ} \mathrm{C}$. The supernatant was used as the extract for the determination of LOX activity. The reaction was initiated by adding $7 \mu \mathrm{L}$ of the extract to a mixture containing $790 \mu \mathrm{L}$ of buffer, $50 \mathrm{mM}$ sodium phosphate buffer ( $\mathrm{pH} 6.5$ ) and $5 \mu \mathrm{L}$ of a $10 \mathrm{mM}$ sodium linoleate substrate. LOX activity was determined according to the method described by Axelrod et al. (1981). The absorbance of the product released by LOX was measured at $234 \mathrm{~nm}$ using a spectrophotometer. A molar extinction coefficient of $25,000 \mathrm{M}^{-1} \mathrm{~cm}^{-1}$ was used to determine LOX

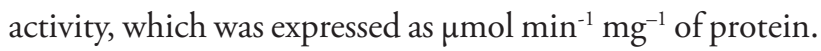

The protein concentration in each sample was determined according to the method of Bradford (1976).

\section{Determination of the malonic aldehyde (MDA) concentration}

Leaf samples were collected as described above. The oxidative damage to lipids was estimated as the total content of the 2-thiobarbituric acid (TBA) reactive substances and expressed as equivalents of malondialdehyde (MDA) according to Cakmak \& Horst (1991) with a few modifications. Briefly, leaf tissue $(0.2 \mathrm{~g})$ was homogenized in $2 \mathrm{~mL}$ of a $0.1 \%$ $(w / v)$ trichloroacetic acid (TCA) solution at $4{ }^{\circ} \mathrm{C}$. After centrifugation at $10,000 \times g$ for $15 \mathrm{~min}, 250 \mu \mathrm{L}$ of the supernatant was incubated with $750 \mu \mathrm{L}$ of TBA $(0.5 \%$ in $20 \%$ TCA) for $20 \mathrm{~min}$ in a boiling water bath. After this period, the reaction was terminated by immersion in an ice bath. The samples were centrifuged at $13,000 \times g$ for $4 \mathrm{~min}$, and the supernatant absorbance was recorded at $532 \mathrm{~nm}$. The MDA concentration formed in each sample was calculated using an extinction coefficient of $155 \mathrm{mMcm}^{-1}$ and expressed as nmol of MDA per $\mathrm{g}$ of fresh weight (FW).

\section{Experimental design and statistical analysis}

Three experiments were performed. In Exp. 1, the bacterial spot severity was evaluated, in Exp. 2, the antagonist populations in the rhizosphere were quantified, and in Exp. 3, leaf tissues samples of non-inoculated (0 dai) or inoculated plants (2, 5 and 11 dai) were obtained for biochemical analyses. Exp. 1 was performed in a completely randomized design with five treatments and five replications. Exp. 2 was performed using a completely randomized design with four treatments (antagonists (UFV252, UFV592 and UFV618) and the control treatment) replications five times. The soil CFU g ${ }^{-1}$ data were transformed using $\log _{10}$ before plotting the antagonist growth curves over time. The five replicates of each treatment were used to calculate the standard error of the mean. Exp. 3 was a $5 \times 4$ factorial experiment arranged in a completely randomized design with five treatments (antagonists [UFV252, UFV592 and UFV618], JA and the control treatment [no antagonists or JA]), four evaluation times (0, 2, 5 and 11 dai) and four replications. Exps. 1, 2 and 3 were repeated once. Data from all variables evaluated in the three experiments were subjected to an analysis of variance. The AUBSPC means were compared using Tukey's test $(\mathrm{p} \leq 0.05)$. In addition, the UFV252, UFV592, UFV618, JA and control means of each evaluation time were compared using Tukey's test $(\mathrm{p} \leq 0.05)$. Each experimental unit in all experiments corresponded to a plastic pot containing one plant. The statistical analyses were performed using SAS (version 6.12; SAS Institute, Inc., Cary, NC, U.S.A.).

\section{RESULTS AND DISCUSSION}

This study provides that treatment with rhizobacteria induced significant protection against $X$. gardneri. The spatial separation between isolates in the rhizosphere and pathogen in the phyloplane excludes the possibility of direct antagonism, leading to the conclusion that systemic resistance was induced.

Until recently, the bacteria causing tomato bacterial spot were grouped into a single species of $X$. axonopodis pv. vesicatoria. Currently, the disease is assigned to at least four taxonomically distinct xanthomonads including Xanthomonas euvesicatoria, X. vesicatoria, X. perforans and X. gardneri (Jones et al., 2004). Because of the recent changes in the taxonomy of these bacteria involved in the tomato bacterial spot complex, there are few studies on induced resistance in tomato against $X$. gardneri infection either using abiotic and or biotic inducers. High density chitosan reduced up to $60 \%$ of the symptoms of tomato bacterial spot caused by $X$. gardneri and increased peroxidase activity by $31 \%$ in treated and inoculated plants compared to the inoculated control group (Jail et al., 2014). Rhizobacteria have also shown effectiveness in the control of tomato bacterial spot through induced systemic resistance (ISR). The B101R, B2121R and A068R isolates of rhizobateria reduced the symptoms of bacterial spot by $50 \%$ on tomato plants inoculated with $X$. campestris pv. vesicatoria, which was identified as $X$. gardneri later on (Silva et al., 2004). 
The final severity and AUBSPC were significantly reduced with the use of the UFV592 and UFV618 antagonists and JA in comparison with the control treatment (Table 1). The UFV592, UFV618 and JA treatments reduced the final severity by $29.44,59.26$ and $61.33 \%$, respectively, in comparison to the control treatment. The use of antagonist UFV618 provided control of bacterial spot of tomato similarly to AJ (Table 1).

There is a lack of registered products that can effectively control bacterial diseases of plants. Consequently, biological control and the induction of resistance are promising alternatives for use in an integrated management program assessing the bacterial etiology of diseases such as bacterial spot of tomato. The antagonist UFV618 effectively induced systemic resistance in tomato plants against $X$. gardneri infection. The absence of direct antagonism against $X$. gardneri in paired culture and also failure to recover the antagonist in tomato shoot when the antagonist was delivery by microbiolized seeds, direct antagonism and competition for space and nutrients were discarded (data not shown).

Indeed, in the present study the UFV618 reduced bacterial spot severity to the same level as the hormone JA and there was an increase in the activity of defense enzymes in tomato leaves and the bacteria population levels remained above $10^{5} \mathrm{CFU} / \mathrm{g}$ soil throughout the experiments. The ISR by PGPR and pathogen-mediated systemic acquired resistance (SAR) has been documented for many plant species and has a broad-spectrum of effectiveness (Kloepper et al., 2004; Van Loon et al., 1998; Yan et al., 2002). Signaling pathways that are activated by PGPR revealed that JA and ethylene are central players in the regulation of ISR and SAR mediated by salicylic acid. Yan et al. (2002) showed that Bacillus pumilus SE34 and Pseudomonas fluorescens 89B61 elicited systemic protection against late blight on tomato and reduced disease severity by a level equivalent to SAR induced by Phytophthora infestans or induced local resistance by amino butyric acid (BABA). The signal transduction pathways used by the PGPR, P. infestans and BABA were evaluated in three

Table 1. Final severity (\%) and area under the bacterial spot progression curve (AUBSPC) of tomato plants inoculated with Xanthomonas gardneri that received the following treatments: antagonists (UFV252, UFV592 and UFV618), jasmonic acid (JA) and control (absence of antagonist and JA)

\begin{tabular}{|ccc|}
\hline Treatments & Final severity (\%) & AUBSPC \\
\hline Control & $17.66 \mathrm{a}$ & $125.80 \mathrm{a}$ \\
\hline UFV252 & $17.26 \mathrm{a}$ & $106.86 \mathrm{a}$ \\
\hline UFV592 & $12.46 \mathrm{~b}$ & $82.34 \mathrm{~b}$ \\
\hline UFV618 & $7.20 \mathrm{c}$ & $56.13 \mathrm{c}$ \\
\hline JA & $6.83 \mathrm{c}$ & $54.50 \mathrm{c}$ \\
\hline CV (\%) & 18.53 & 12.44 \\
\hline
\end{tabular}

Means followed by the same letter are not significantly different ( $\mathrm{p} \leq 0.05$; Tukey's test). Two experiments were conducted with consistent results; the data represent the best experiment. $n=5$. tomato lines: salicylic acid (SA)- hydroxylase transgenic tomato $(n a b G)$, ethylene insensitive mutants $(N r / N r)$ and jasmonic acid insensitive mutants (def1) (Yan et al., 2002). The results obtained by these authors suggested that induced protection elicited by PGPR strains was ethylene and jasmonic acid-dependent, but SA-independent, whereas protection elicited by the pathogen and induced resistance by BABA were SA-dependent. Therefore, the analysis of JA- signaling mutants has helped to elucidate the role of JA in the regulation of PGPR-triggered systemic defense responses (Yan et al., 2002).

The colonization of the roots by ISR-inducing PGPR is often not associated with an increase in the production of JA (Pieterse et al., 2000). Hence, ISR seems to be based on increased sensitivity rather than on increased production of this hormone. In the present study, it was observed faster and higher activities of defense enzymes in plants that were sprayed with $\mathrm{AJ}$ and or treated with UFV618. This PGPR-mediated sensitization of the plant tissue for enhanced defense expression is called 'priming' and is characterized by a faster and or stronger activation of cellular defenses upon pathogen or insect attack resulting in enhanced host resistance (Van der Ent et al., 2009).

The JA hormone is an important plant signaling molecule involved in a variety of critical functions including defense response against pest and pathogen attack (Creelman \& Mullet, 1997). The signaling of JA leads to the induction of the PR proteins: PR-3, a basic chitinase; PR-4, a chitin-binding protein; and PDF1.2, which is a member of the group of plant defensins, a family of peptides with antimicrobial activities (Van Loon \& Van Strien, 1999). In a study using tomato plants incapable of producing JA (def1), plants inoculated with five of eight pathogens were more susceptible to Pseudomonas syringae, $X$. campestris, Verticillium dahlia, Fusarium oxysporum f.sp. lycopersici and Phytophthora infestans. When the def1 plants were sprayed with JA, the resistance was re-established and was similar to the wild type plants (Thaler et al., 2004). The results obtained in the present study are consistent with the findings of Yan et al. (2002) and Thaler et al. (2004) and highlight the importance of Streptomyces setonii (UFV618) and JA to tomato resistance against bacterial spot.

The population dynamics of the UFV252, UFV592 and UFV618 antagonists tended to equilibrate over time (Figure 1). However, there was a sharper decline in the UFV252 population from 15 to 37 days after its second application. The population of this antagonist was $3.5 \times 10^{5}$ and $7.26 \times 10^{3} \mathrm{CFU} / \mathrm{g}$ soil at 15 and 22 days, respectively, after its second application. There was an increase in the population of the antagonists after their second application; the population levels of UFV252, UFV592 and UFV618 were 163, 168 and 21 times higher, respectively, in comparison to the levels prior to the second application. Throughout the experiment, the average populations of UFV252, UFV592 and UFV618 
were $1.85 \times 10^{6}, 4.77 \times 10^{5}$ and $1.52 \times 10^{5} \mathrm{CFU} / \mathrm{g}$ soil, respectively (Figure 1). The antagonists did not grow in their respective semi-selective media in the control treatment. The second antagonist application efficiently increased the population levels in both the rhizoplane and the rhizosphere of the tomato plants.

The minimum antagonist concentration needed for the biocontrol of tomato bacterial spot and the delivery of the antagonists through seed microbiolization is not known. Therefore, a second antagonist delivery by soil drenching was performed five days before inoculating the plants with $X g$. Failure to elicit ISR may result from the lack of production of inducing components by the antagonist or the inability of the plant species to perceive such inducing compounds (Van Loon, 2007). Generally, a population density of approximately $10^{5}$ colony-forming units per gram of root is required for resistance induction in plants (Raaijmakers et al., 1995), which suggests that quorum-sensing signals are necessary for the production of resistance components. The population levels of UFV592 and UFV618 remained constant after their second delivery. According to Romeiro (2007), particular bacteria can be considered as rhizobacteria if they are able to survive and

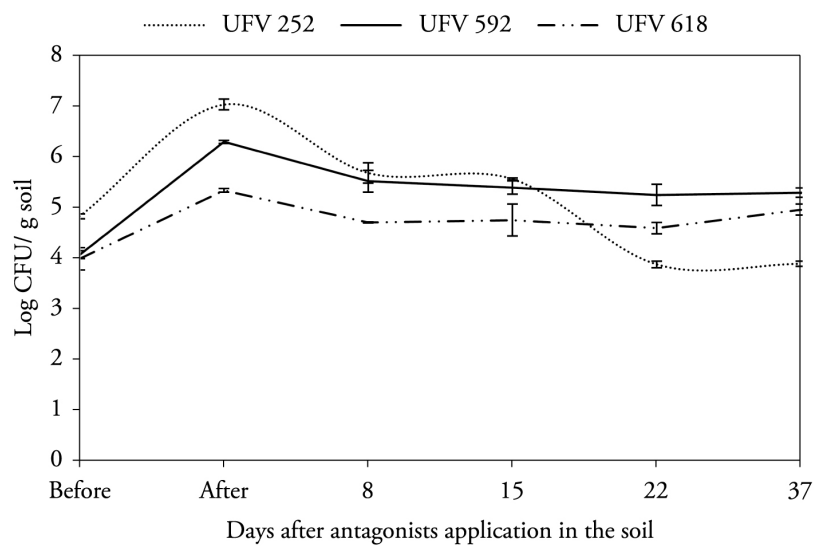

Figure 1. Population dynamics of the three antagonists (UFV252, UFV592 and UFV618) before their second application (Before), after their second application (After) and from 8 to 37 days after their addition to the soil. The bars represent the standard error of the means. Two experiments were conducted with consistent results; the data represent the best experiment. $n=5$. multiply in the rhizosphere and rhizoplane of a target plant, and a high population level can be maintained for biocontrol purposes. There was considerable fluctuation in the population levels of UFV252 throughout the evaluation period, which was likely due to the non-production of endospores by this strain.

It was hypothesized that UFV252, UFV592 and UFV618 can induce resistance in tomato plants against $X$. gardneri because these antagonists were previously selected for their ability to reduce the severity of some tomato diseases and observed biological control was not due to the direct antagonism. The induced systemic resistance promoted by rhizobacteria occurs through a more rapid and/or stronger activation of cellular defenses upon invasion, resulting in an enhanced level of plant resistance (Van Loon, 2007). This type of response was observed in the present study by the higher activities of the defense enzymes, especially in the plants treated with UFV618. Non-pathogenic rhizobacteria may activate inducible defense mechanisms in plants in a similar way to pathogenic microorganisms. Thus, the plant could identify the antagonist as a potential threat and trigger the production of resistance-eliciting compounds that act similar to elicitors produced by plant pathogenic fungi and bacteria (Van Loon, 2007). This finding is in agreement with the results from the present study considering that the enzyme activities increased in the non-inoculated plants (0 dai) treated with the antagonists (Figure 2b-d).

The effect of all treatment, the evaluation times and their interactions were significant for all defense enzymes and the MDA concentration (Table 2). The antagonists increased the activities of most of the defense enzymes for at least one evaluation time, but only UFV618 and JA increased the activity of all defense enzymes. These results and those obtained from the disease severity investigation reveal that UFV592 and UFV618 can induce resistance in tomato plants against bacterial spot.

There was no significant difference in the POX activity between the treatments and the control at 0 dai (Figure 2a). POX activity was significantly higher in the UFV592, UFV618 and JA treatments at 2 dai, in the UFV618 and JA treatments at 5 dai and in all treatments at 11 dai compared with the control (Figure 2a). POX activity in the UFV618 and JA treatments was at least 1.5 times higher than in the control treatment 2 dai. Recent investigations on the biological control

Table 2. Analysis of variance of the effects of treatments (antagonists UFV252, UFV592 and UFV618; jasmonic acid and control) and evaluation times for peroxidase (POX), polyphenoloxidase (PPO), $\beta$-1,3-glucanase (GLU), chitinase (CHI), phenylalanine ammonia-lyase (PAL) and lipoxygenase (LOX) activities and malonic aldehyde (MDA) concentration

\begin{tabular}{|c|c|c|c|c|c|c|c|c|}
\hline \multirow{2}{*}{ Sources of variation } & \multicolumn{8}{|c|}{$F$ values } \\
\hline & df & POX & PPO & GLU & CHI & PAL & LOX & MDA \\
\hline Treatments (T) & 4 & $39.17^{* *}$ & $93.81^{* *}$ & $9.02^{* *}$ & $97.24^{* *}$ & $39.06^{* *}$ & $1.15^{*}$ & $43.03^{* *}$ \\
\hline Evaluation times (ET) & 3 & $303.67^{* *}$ & $115.17^{* *}$ & $25.96^{* *}$ & $84.63^{* *}$ & $56.27^{* *}$ & $29.15^{* *}$ & $14.18^{* *}$ \\
\hline $\mathrm{T} \times \mathrm{ET}$ & 12 & $9.95^{* *}$ & $9.56 * *$ & $4.62^{* *}$ & $25.24^{* *}$ & $24.68^{* *}$ & $8.51^{* *}$ & $2.57^{* *}$ \\
\hline
\end{tabular}

Levels of probability: ${ }^{*}$ and ${ }^{* *}=$ significative at 0.05 and 0.01 , respectively. 

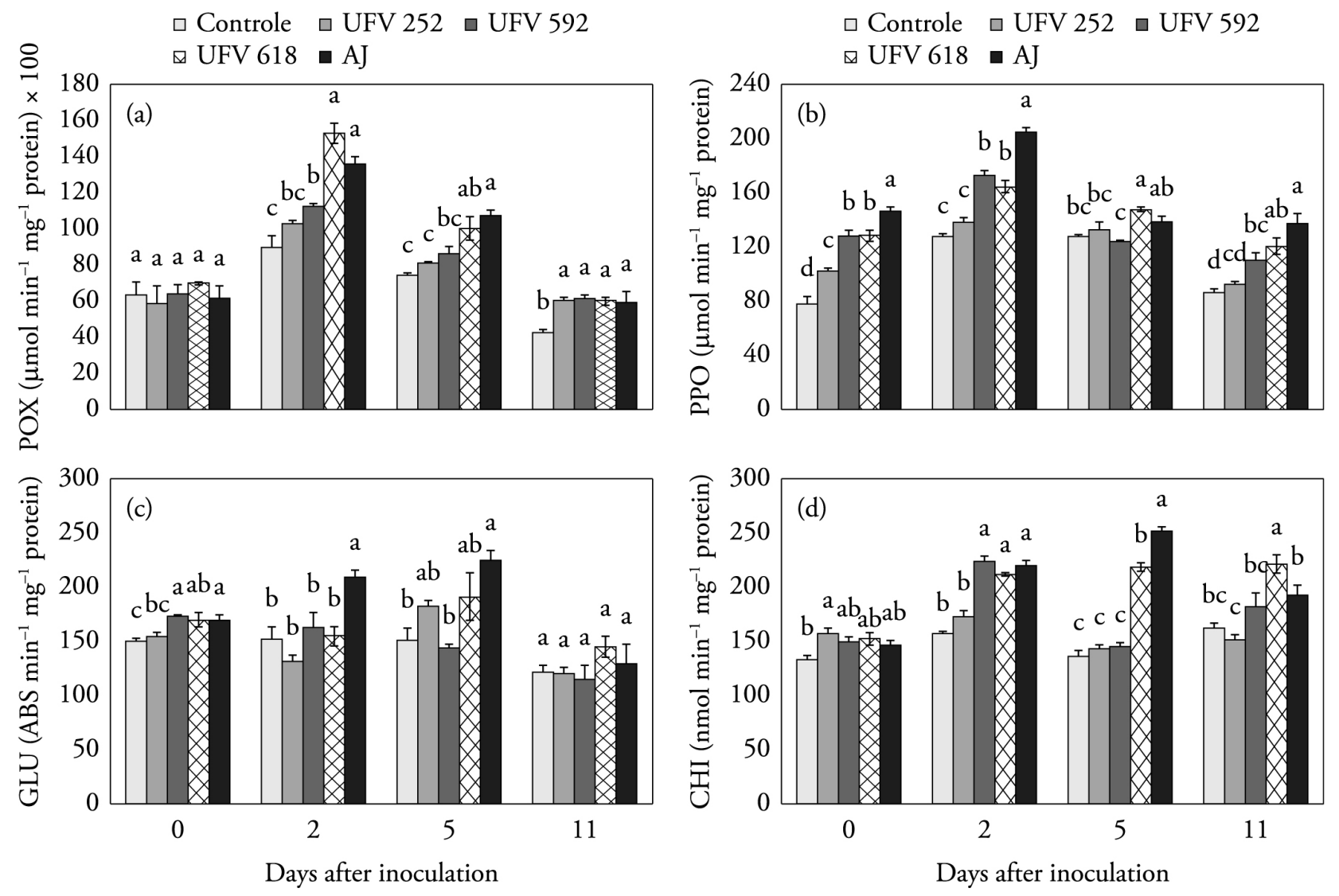

Figure 2. Activities of peroxidase (POX) (a), polyphenoloxidase (PPO) (b), $\beta$-1,3-glucanase (GLU) (c) and chitinase (CHI) (d) in the leaf tissue of tomato plants inoculated with Xanthomonas gardneri and subjected to the following treatments: control (absence of antagonist and JA), the antagonists UFV252, UFV592 and UFV618, and jasmonic acid. The bars represent the standard error of the means. Means followed by the same letter are not significantly different ( $\mathrm{p} \leq 0.05$; Tukey's test). Two experiments were conducted with consistent results; the data represent the best experiment. $n=4$.

mechanisms of PGPR revealed that several strains protect plants from pathogen attack through an increase in POX activity (Ferraz et al., 2014; Ganeshamoorthi et al., 2008; Vanitha \& Umesha, 2011). This enzyme is important for the lignification of plant tissues, and lignin precursors exhibit antimicrobial activity (Ride, 1975).

The initial PPO activity (0 dai) was significantly higher in the treatments compared with the control (Figure 2b). PPO activity was significantly higher in the UFV592, UFV618 and JA treatments 2 and 11 dai and in the UFV618 treatment 5 dai compared with the control (Figure 2b). PPO catalyzes the oxidation of phenolic compounds into highly toxic quinines, which play an important role in plant disease resistance (Campbell \& Sederoff, 1996). In the present study, tomato plants treated with UFV592 and UFV618 antagonists or sprayed with JA showed an increase in PPO activity. Maximum PPO activity was measured 2 dai in plants treated with UFV592, UFV618 and JA.

GLU activity was significantly higher in the UFV592, UFV618 and JA treatments 0 dai and in the JA treatment 2 and 5 dai compared with the control (Figure 2c). There was no significant difference in the GLU activity between the treatments and the control 11 dai (Figure 2c). "Lower fungi" belonging to the Chromista kingdom and Peronosporales order are important pathogens in higher plants and contain glucan as a cell wall constituent. One of the main modes of antagonistic activity of PGPR is the production of lytic enzymes ( $\beta-1,3$ glucanases), which act on the cell walls of Peronosporales members (Mathiyazhagan et al., 2004) and also through ISR in plants. Maurhofer et al. (1994) reported that $\beta-1,3$ glucanases were induced in the intercellular fluid of tobacco leaves of plants grown in the presence of Pseudomonas fluorescens strain CHAO. However, despite the increased activity of GLU in the UFV592, UFV618, and JA treatments in the present study, the function of this hydrolytic enzyme in plant resistance to infection by bacterial pathogens remains poorly known (Cavalcanti et al., 2006). Tomato plants treated with acibenzolar-S-methyl four days before inoculation with $X$. vesicatoria exhibited increased activities of CHI and GLU and lower severity of bacterial spot (Cavalcanti et al., 2006).

CHI activity was significantly higher in the UFV252 treatment 0 dai, in the UFV592, UFV618 and JA treatments 2 dai, in the UFV618 and JA treatments 5 dai, and in the 

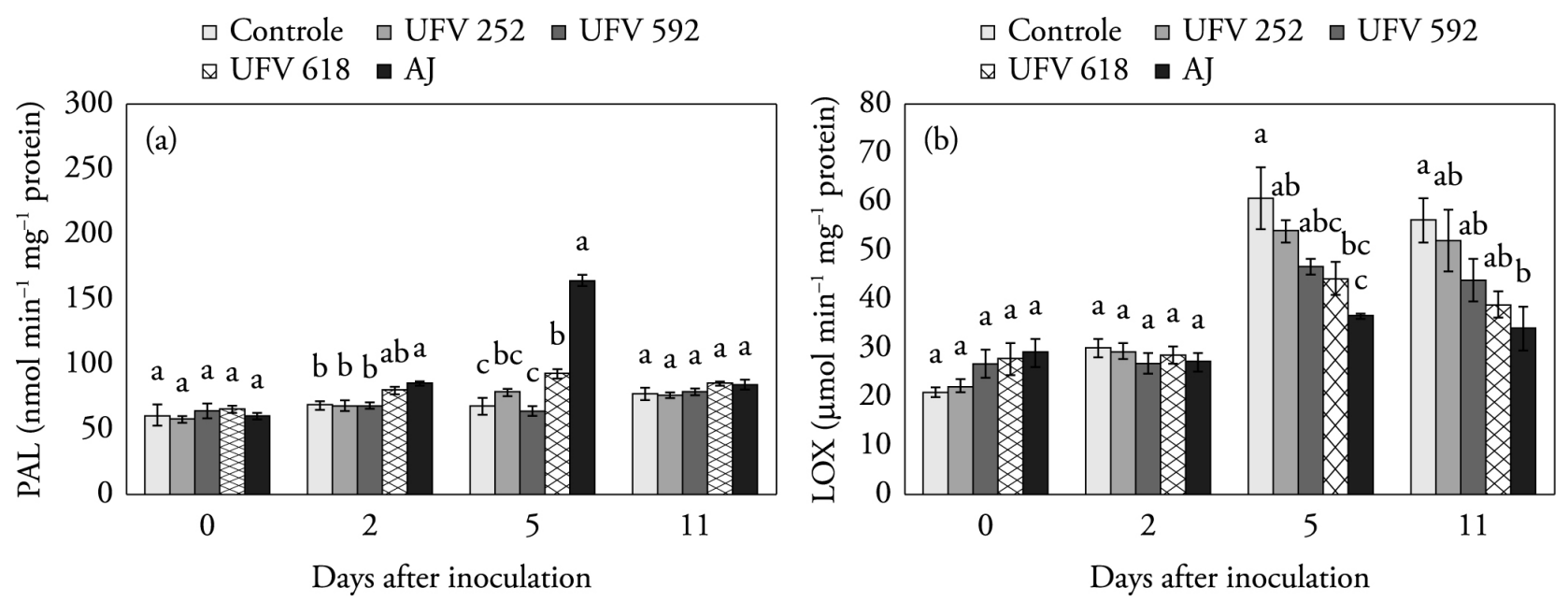

Figure 3. Activities of phenylalanine ammonia-lyase (PAL) (a) and lipoxygenase (LOX) (b) in the leaf tissue of tomato plants inoculated with Xanthomonas gardneri and subjected to the following treatments: control (absence of antagonist and JA), the antagonists UFV252, UFV592 and UFV618, and jasmonic acid. The bars represent the standard error of the means. Means followed by the same letter are not significantly different ( $\mathrm{p} \leq 0.05$; Tukey's test). Two experiments were conducted with consistent results; the data represent the best experiment. $n=4$.

UFV618 treatment 11 dai compared with the control (Figure 2d). CHI catalyzes the hydrolysis of chitin (Keen \& Yoshikawa, 1983). In addition, purified CHI can release chitin oligomers from fungal cell walls and acts in a similar manner as lysozyme on bacterial cell walls (Herget et al., 1990; Schlumbaum et al., 1986). Tobacco plants overexpressing the Trichoderma harzianum endochitinase-encoding gene pschit33 were resistant to bacterial leaf spot caused by Pseudomonas syringae (Dana et al., 2006).

There was no significant difference in the PAL activity between the treatments and the control at 0 or 11 dai (Figure 3a). PAL activity was significantly higher in the JA treatment 2 dai and in the UFV618 and JA treatments 5 dai compared with the control (Figure 3a). PAL is the first enzyme of the phenylpropanoid pathway and catalyzes the conversion of phenylalanine to trans-cinnamic acid (Camm $\&$ Towers, 1973). The functions of PAL in the formation of phenylpropanoid compounds include preformed or inducible physical and chemical barriers such as lignin and secondary metabolites against infection and this enzyme plays an important role in plant disease resistance (Dixon et al., 2002). Kurth et al. (2014) observed that PAL activity increased in pedunculate oak leaves after inoculation with Microsphaera alphitoides and Streptomyces sp. strain AcH 505; however, this change in activity was most significant after co-inoculation with the bacterium and fungus. In the present study, the UFV618 and JA treatments had PAL activities that were 1.4 and 2.4 times higher, respectively, compared with the control 5 dai.

There was no significant difference in the LOX activity between the treatments and the control at 0 or 2 dai (Figure 3b). LOX activity was significantly lower in the UFV618 and JA treatments 5 dai and in the JA treatment
11 dai compared with the control (Figure $3 \mathrm{~b}$ ). The addition of a single electron to LOX from fatty acids and $\mathrm{O}_{2}$ converts molecular oxygen into the superoxide anion radical $\left(\mathrm{O}_{2}^{-}\right)$ (Doke et al., 1996). During infection by pathogens, the plasma membrane of the host plant is degraded, which results in the release of fatty acids that serve as a substrate for LOX. In the present study, the highest LOX activities were observed in the UFV252 and control treatments; the greatest severity of tomato bacterial spot was also observed in these treatments. However, higher LOX activity may result in the production of hydroperoxide as a product of the degradation of fatty acids, which may induce pathogen resistance in certain plants (Silva et al., 2001).

There was no significant difference in the MDA concentration between the treatments and the control 0 dai (Figure 4). The MDA concentration was significantly lower in the UFV618 and JA treatments 2 dai and in the UFV592, UFV618 and JA treatments at 5 and 11 dai compared with the control (Figure 4). MDA is an indirect indicator of lipid peroxidation in the cell wall membrane (Cakmak \& Horst, 1991).The MDA levels in the present study confirm the reduced bacterial spot symptoms on the leaves and indirectly, the reduced $X$. gardneri colonization of the leaf tissue of tomato plants treated with UFV618, UFV592 or JA in comparison with the control. Reduced lipid peroxidation in the plasma membrane can also be linked to an increase in POX activity on tomato plants treated with UFV592, UFV618 or JA. Upon bacterial infection, the cell membrane suffers physical damage, with the sequential LOX-initiated degradation of lipids (Alami et al., 1999). The greater bacterial spot symptoms on the tomato plants in the control treatment were linked to a higher MDA concentration and enhanced LOX activity. 


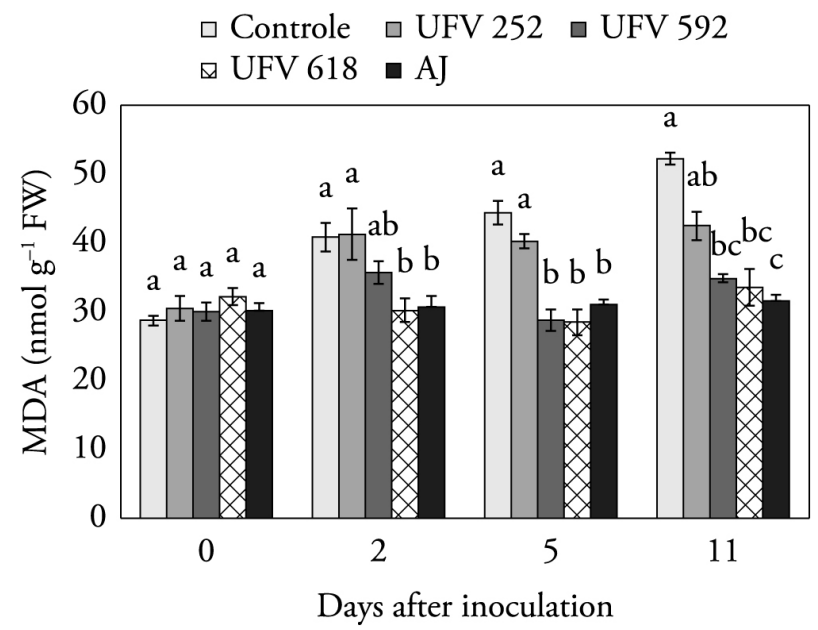

Figure 4. Concentration of malonic aldehyde (MDA) in the leaf tissue of tomato plants inoculated with Xanthomonas gardneri and subjected to the following treatments: control (absence of antagonist and JA), the antagonists UFV252, UFV592 and UFV618, and jasmonic acid. The bars represent the standard error of the means. Means followed by the same letter are not significantly different ( $\mathrm{p} \leq 0.05$; Tukey's test). Two experiments were conducted with consistent results; the data represent the best experiment. FW $=$ fresh weight. $n=4$.

\section{CONCLUSION}

The results of the present study indicate that the UFV618 antagonist was as effective as the hormone JA in reducing bacterial spot symptoms on tomato leaves. Tomato plants that received UFV592, UFV618 or JA treatment exhibited lower bacterial spot severity and higher POX, PPO, GLU, $\mathrm{CHI}$ and PAL activities compared with the control plants.

\section{ACKNOWLEDGEMENTS}

Prof. F.A. Rodrigues thanks the CNPq for his fellowship. This study was financed by CAPES, CNPq and FAPEMIG.

\section{REFERENCES}

Alami, I., Jouy, N., \& Clerivet, A. (1999). The lipoxygenase pathway is involved in elicitor-induced phytoalexin accumulation in plane tree (Platanus acerifolia) cell-suspension cultures. Journal of Phytopathology-Phytopathologische Zeitschrift, 147, 515-519. http://dx.doi.org/10.1111/j.1439-0434.1999.tb03858.x.

Axelrod, B., Cheesbrough, T. M., \& Laakso, S. (1981). Lipoxygenases from soybeans. Methods in Enzymology, 71, 441-451. http://dx.doi. org/10.1016/0076-6879(81)71055-3.

Bradford, M. M. (1976). A rapid and sensitive method for the quantitation of microgram quantities of protein utilizing the principle of protein-dye binding. Analytical Biochemistry, 72, 248-254. http:// dx.doi.org/10.1016/0003-2697(76)90527-3. PMid:942051.

Brasil. Ministério da Agricultura. Sistema de Agrotóxicos Fitossanitários - AGROFIT. (2015). Plataforma de pesquisa de agrotóxicos registrados para o Brasil. Brasília/DF: Ministério da Agricultura. Retrieved in 3 February 2015, from http://extranet.agricultura.gov.br/agrofit_cons/ principal_agrofit_cons

Cakmak, L., \& Horst, W. J. (1991). Effect of aluminum on lipid peroxidation, superoxide dismutase, catalase, and peroxide activity in root tip of soybean (Glicine max). Plant Physiology, 83, 463-468. http://dx.doi.org/10.1111/j.1399-3054.1991.tb00121.x.

Camm, E. L., \& Towers, G. (1973). Phenylalanine ammonia lyase. Phytochemistry, 12, 961-973. http://dx.doi.org/10.1016/00319422(73)85001-0.

Campbell, M. M., \& Sederoff, R. R. (1996). Variation in lignin contend and composition (Mechanisms of Control and Implications for the Genetic Improvement of Plants). Plant Physiology, 110, 3-13. PMid:12226169.

Cavalcanti, F. R., Resende, M. L. V., Pereira, R. B., Costa, J. C. B., \& Carvalho, C. P. S. (2006). Atividades de quitinase e beta-1,3-glucanase após eliciação das defesas do tomateiro contra a mancha-bacteriana. Pesquisa Agropecuaria Brasileira, 41, 1721-1730. http://dx.doi. org/10.1590/S0100-204X2006001200006.

Chance, B., \& Maehly, A. C. (1955). Assay of catalases and peroxidases. Methods in Enzymology, 2, 764-775. http://dx.doi.org/10.1016/ S0076-6879(55)02300-8.

Creelman, R. A., \& Mullet, J. E. (1997). Biosynthesis and action of jasmonates in plants. Annual Review of Plant Physiology and Plant Molecular Biology, 48, 355-381. http://dx.doi.org/10.1146/annurev. arplant.48.1.355. PMid:15012267.

Dana, M. M., Pintor-Toro, J. A., \& Cubero, B. (2006). Transgenic tobacco plants overexpressing chitinases of fungal origin show enhanced resistance to biotic and abiotic stress agents. Plant Physiology, 142, 722-730. http://dx.doi.org/10.1104/pp.106.086140. PMid:16891545.

Dixon, R. A., Achnine, L., Kota, P., Liu, C. J., Reddy, M. S. S., \& Wang, L. (2002). The phenylpropanoid pathway and plant defence-a genomics perspective. Molecular Plant Pathology, 3, 371-390. http:// dx.doi.org/10.1046/j.1364-3703.2002.00131.x. PMid:20569344.

Doke, N., Miura, Y., Sanchez, L. M., Park, H. J., Noritake, T., Yoshioka, H., \& Kawakita, K. (1996). The oxidative burst protects plants against pathogen attack: mechanism and role as an emergency signal for plant bio-defence--a review. Gene, 179, 45-51. http://dx.doi. org/10.1016/S0378-1119(96)00423-4. PMid:8955628.

Ferraz, H. G. M., Resende, R. S., Silveira, P. R., Andrade, C. C. L., Milagres, E. A., Oliveira, J. R., \& Rodrigues, F. A. (2014). Rhizobacteria induces resistance against Fusarium wilt of tomato by increasing the activity of defense enzymes. Bragantia, 73, 274-283. http://dx.doi. org/10.1590/1678-4499.0124.

Ferraz, H. G. M., Souza, A. N., Garcia, F. A. O., \& Romeiro, R. S. (2010). Elaboração de um meio semi-seletivo com base na resistência múltipla constitutiva de Pseudomonas putida (UFV-0073) a antibióticos. Revista Trópica: Ciências Agrárias e Biológicas, 4, 17-24. 
Fujimoto, T., Tomitaka, Y., Abe, H., Tsuda, S., Futai, K., \& Mizukubo, T. (2011). Expression profile of jasmonic acid-induced genes and the induced resistance against the root-knot nematode (Meloidogyne incognita) in tomato plants (Solanum lycopersicum) after foliar treatment with methyl jasmonate. Journal of Plant Physiology, 168, 1084-1097. http://dx.doi.org/10.1016/j.jplph.2010.12.002. PMid:21216026.

Ganeshamoorthi, P., Anand, T., Prakasam, V., Bharani, M., Ragupathi, N., \& Samiyappan, R. (2008). Plant growth promoting rhizobacterial (PGPR) bioconsortia mediates induction of defenserelated proteins against infection of root rot pathogen in mulberry plants. Journal of Plant Interactions, 3, 233-244. http://dx.doi. org/10.1080/17429140802088097.

Harman, G. E., Hayes, C. K., Lorito, M., Broadway, R. M., Di Pietro, A., Peterbauer, C., \& Tronsmo, A. (1993). Chitinolytic enzymes of Trichoderma harzianum, purification of chitobiosidase and endochitinase. Phytopathology, 83, 313-318. http://dx.doi. org/10.1094/Phyto-83-313.

Herget, T., Schell, J., \& Schreier, P. H. (1990). Elicitor-specific induction of one member of the chitinase gene family in Arachis hypogaea. Molecular \& General Genetics, 224, 469-476. http:// dx.doi.org/10.1007/BF00262442. PMid:1980004.

Jail, N. G., Luiz, C., Rocha, A. C., No., \& Di Piero, R. M. (2014). High-density chitosan reduces the severity of bacterial spot and activates the defense mechanisms of tomato plants. Tropical Plant Pathology, 39, 434-441. http://dx.doi.org/10.1590/S1982-56762014000600003.

Jones, J. B., Lacy, G. H., Bouzar, H., Stall, R. E., \& Schaad, N. W. (2004). Reclassification of the xanthomonads associated with bacterial spot disease of tomato and pepper. Systematic and Applied Microbiology, 27, 755-762. http://dx.doi.org/10.1078/0723202042369884. PMid:15612634.

Kado, C. I., \& Heskett, M. G. (1970). Selective media for isolation of Agrobacterium, Corynebacterium, Erwinia, Pseudomonas, and Xanthomonas. Phytopathology, 60, 969-976. http://dx.doi.org/10.1094/ Phyto-60-969. PMid:5469886.

Kar, M., \& Mishra, D. (1976). Catalase, peroxidase and polyphenoloxidase activities during rice leaf senescence. Plant Physiology, 57, 315-319. http://dx.doi.org/10.1104/pp.57.2.315. PMid:16659474.

Keen, N. T., \& Yoshikawa, M. (1983). beta-1,3-Endoglucanase from soybean releases elicitor-active carbohydrates from fungus cell walls. Plant Physiology, 71, 460-465. http://dx.doi.org/10.1104/ pp.71.3.460. PMid:16662849.

Kloepper, J. W., Ryu, C. M., \& Zhang, S. (2004). Induced systemic resistance and promotion of plant growth by Bacillus spp. Phytopathology, 94, 1259-1266. http://dx.doi.org/10.1094/PHYTO.2004.94.11.1259. PMid:18944464.

Kúc, J. (2001). Concepts and direction of induced systemic resistance in plants its application. European Journal of Plant Pathology, 107, 7-12. http://dx.doi.org/10.1023/A:1008718824105.

Kurth, F., Mailänder, S., Bönn, M., Feldhahn, L., Herrmann, S., Große, I., Buscot, F., Schrey, S. D., \& Tarkka, M. T. (2014). Streptomycesinduced resistance against oak powdery mildew involves host plant responses in defense, photosynthesis, and secondary metabolism pathways. Molecular Plant-Microbe Interactions, 27, 891-900. http://dx.doi.org/10.1094/MPMI-10-13-0296-R. PMid:24779643.

Lanna, R., Fo., Souza, R. M., Ferreira, A., Quecine, M. C., Alves, E., \& Azevedo, J. L. (2013). Biocontrol activity of Bacillus against a GFP-marked Pseudomonas syringae pv. tomato on tomato phylloplane. Australasian Plant Pathology, 42, 643-651. http://dx.doi.org/10.1007/ s13313-013-0233-z.

Lever, M. (1972). A new reaction for colorimetric determination of carbohydrates. Analytical Biochemistry, 47, 273-279. http://dx.doi. org/10.1016/0003-2697(72)90301-6. PMid:5031119.

Lopes, M. C., \& Stripari, P. C.(1998). A cultura do tomateiro. In R. Goto, \& S. W. Tivelli. Produção de hortaliças em ambiente protegido: condiçôes subtropicais (p. 257-304). São Paulo: Fundação Editora UNESP.

Louws, F. J., Fulbright, D. W., Stephens, C. T., \& Bruijn, F. J. (1995). Differentiation of genomic structure by rep-PCR fingerprinting to rapidly classify Xanthomonas campestris pv. vesicatoria. Phytopathology, 85, 528-536. http://dx.doi.org/10.1094/Phyto-85-528.

Mathiyazhagan, S., Kavitha, K., Nakkeeran, S., Chandrasekar, G., Manian, K., Renukadevi, P., Krishnamoorthy, A. S., \& Fernando, W. G. D. (2004). PGPR mediated management of stem blight of Phyllanthus amarus (Schum and Thonn) caused by Corynespora cassiicola (Berk and Curt) Wei. Archives of Phytopathology and Plant Protection, 37, 183-199. http://dx.doi.org/10.1080/03235400410001730658.

Maurhofer, M., Hase, C., Maurwly, D., Metranx, J. P., \& Defago, G. (1994). Induction of systemic resistance of tobacco to tobacco necrosis virus by the root colonizing Pseudomonas fluorescens strain CHAO: influence of the gac $A$ gene and of pyoverdine production. Phytopathology, 84, 139-146. http://dx.doi.org/10.1094/Phyto-84-139.

Mello, S. C. M., Takatsu, A., \& Lopes, C. A. (1997). Escala diagramática para avaliação da mancha-bacteriana do tomateiro. Fitopatologia Brasileira, 22, 447-448.

Nafie, E., Hathout, T., \& Al Mokadem, A. S. (2011). Jasmonic acid elicits oxidative defense and detoxification systems in Cucumis melo L. cells. Brazilian Journal of Plant Physiology, 23, 161-174. http:// dx.doi.org/10.1590/S1677-04202011000200008.

Pieterse, C. M. J., Van Pelt, J. A., Ton, J., Parchmann, S., Mueller, M. J., Buchala, A. J., Métraux, J. P., \& Van Loon, L. C. (2000). Rhizobacteria-mediated induced systemic resistance (ISR) in Arabidopsis requires sensitivity to jasmonate and ethylene but is not accompanied by an increase in their production. Physiological and Molecular Plant Pathology, 57, 123-134. http://dx.doi.org/10.1006/pmpp.2000.0291.

Pieterse, C. M. J., Zamioudis, C., Berendsen, R. L., Weller, D. M., Van Wees, S. C. M., \& Bakker, P. A. H. M. (2014). Induced systemic resistance by beneficial microbes. Annual Review of Phytopathology, 52, 347-375. http://dx.doi.org/10.1146/annurev-phyto-082712-102340. PMid:24906124.

Pramer, D., \& Schmidt, E. L. (1964). Experimental soil microbiology. Minnesota: Burgess. 107 p.

Quezado-Duval, A. M., Leite, R. P., Jr., Truffi, D., \& Camargo, L. E. A. (2004). Outbreaks of bacterial spot caused by Xanthomonas gardneri on processing tomato in Central-West Brazil. Plant Disease, 88, 157-161. http://dx.doi.org/10.1094/PDIS.2004.88.2.157. 
Raaijmakers, J. M., Leeman, M., Van Oorschot, M. P. M., Van Der Sluis, I., Schippers, B., \& Bakkers, P. A. H. M. (1995). Doseresponse relationships in biological control of fusarium wilt of radish by Pseudomonas spp. Phytopathology, 85, 1075-1081. http://dx.doi. org/10.1094/Phyto-85-1075.

Ride, J. P. (1975). Liginification in wounded wheat leaves in response to fungi and its possible role in resistance. Physiological Plant Pathology, 5, 125-134. http://dx.doi.org/10.1016/0048-4059(75)90016-8.

Roberts, W. K., \& Selitrennikoff, C. P. (1988). Plant and bacterial chitinases differ in antifungal activity. Journal of General Microbiology, 134, 169-176. http://dx.doi.org/10.1099/00221287-134-1-169.

Romeiro, R. S. (2005). Bactérias fitopatogênicas. Viçosa: Editora UFV. 417 p.

Romeiro, R. S. (2007). Controle biológico de plantas: fundamentos. Viçosa: Editora UFV. 269 p.

Schlumbaum, A., Mauch, F., Vogeli, U., \& Boller, T. (1986). Plant chitinases are potent inhibitors of fungal growth. Nature, 324, $365-$ 367. http://dx.doi.org/10.1038/324365a0.

Shaner, G., \& Finney, R. F. (1997). The effects of nitrogen fertilization on the expression of show-mildwing in knox wheat. Phytopathology, 67, 1051-1055. http://dx.doi.org/10.1094/phyto-67-1051.

Shanmugam, V., \& Kanoujia, N. (2011). Biological management of vascular wilt of tomato caused by Fusarium oxysporum f.sp lycospersici by plant growth-promoting rhizobacterial mixture. Biological Control, 57, 85-93. http://dx.doi.org/10.1016/j.biocontrol.2011.02.001.

Silva, H. S. A., Romeiro, R. D., Macagnan, D., Halfeld-Vieira, B. D., Pereira, M. C. B., \& Mounteer, A. (2004). Rhizobacterial induction of systemic resistance in tomato plants: non-specific protection and increase in enzyme activities. Biological Control, 29, 288-295. http:// dx.doi.org/10.1016/S1049-9644(03)00163-4.

Silva, M. D., Oliveira, M. G. A., Lanna, A. C., Pires, C. V., Piovesan, N. D., Jose, I. C., Batista, R. B., Barros, E. G., \& Moreira, M. A. (2001). Caracterização da via das lipoxigenases em plantas de soja resistentes e susceptíveis a Diaporthe phaseolorum f.sp. meridionalis, agente causal do cancro-da-haste. Revista Brasileira de Fisiologia Vegetal, 13, 316-328. http://dx.doi.org/10.1590/S0103-31312001000300007.

Thaler, J. S., Owen, B., \& Higgins, V. J. (2004). The role of the jasmonate response in plant susceptibility to diverse pathogens with a range of lifestyles. Plant Physiology, 135, 530-538. http://dx.doi. org/10.1104/pp.104.041566. PMid:15133157.

Van der Ent, S., Van Wees, S. C., \& Pieterse, C. M. (2009). Jasmonate signaling in plant interactions with resistance-inducing beneficial microbes. Phytochemistry, 70, 1581-1588. http://dx.doi.org/10.1016/j. phytochem.2009.06.009. PMid:19712950.

Van Loon, L. C. (2007). Plant responses to plant growth-promoting rhizobacteria. European Journal of Plant Pathology, 119, 243-254. http://dx.doi.org/10.1007/s10658-007-9165-1.

Van Loon, L. C., \& Van Strien, E. A. (1999). The families of pathogenesis related proteins, their activities, and comparative analysis of PR-1 type proteins. Physiological and Molecular Plant Pathology, 55, 85-97. http://dx.doi.org/10.1006/pmpp.1999.0213.

Van Loon, L. C., Bakker, P. A. H. M., \& Pieterse, C. M. J. (1998). Systemic resistance induced by rhizosphere bacteria. Annual Review of Phytopathology, 36, 453-483. http://dx.doi.org/10.1146/annurev. phyto.36.1.453. PMid:15012509.

Van Loon, L. C., Rep, M., \& Pieterse, C. M. (2006). Significance of inducible defense-related proteins in infected plants. Annual Review of Phytopathology, 44, 135-162. http://dx.doi.org/10.1146/annurev. phyto.44.070505.143425. PMid:16602946.

Vanitha, S. C., \& Umesha, S. (2011). Pseudomonas fluorescens-mediated systemic resistance in tomato is driven through an elevated synthesis of defense enzymes. Biologia Plantarum, 55, 317-322. http://dx.doi. org/10.1007/s10535-011-0045-3.

Yan, Z., Reddy, M. S., Ryu, C. M., McInroy, J. A., Wilson, M., \& Kloepper, J. W. (2002). Induced systemic protection against tomato late blight elicited by plant growth-promoting rhizobacteria. Phytopathology, 92, 1329-1333. http://dx.doi.org/10.1094/PHYTO.2002.92.12.1329. PMid:18943888.

Yoshikawa, M., Keen, N. T., \& Wang, M. C. (1983). A receptor on soybean membranes for a fungal elicitor of phytoalexin accumulation. Plant Physiology, 73, 497-506. http://dx.doi.org/10.1104/pp.73.2.497. PMid:16663246.

Zucker, M. (1965). Induction of phenylalanine deaminase by light and its relation to chlorogenic acid synthesis in potato tuber tissue. Plant Physiology, 40, 779-784. http://dx.doi.org/10.1104/pp.40.5.779. PMid:16656157. 